\title{
Library/classroom partnerships for
}

\section{the 1990s}

\author{
By Barbara B. Moran
}

Associate Professor, School of Library and Information Science

University of North Carolina at Chapel Hill

\section{Increasing active learning in undergraduate education.}

$\mathbf{0}$

ver one hundred and twenty-five years ago, Ralph Waldo Emerson chided colleges for establishing libraries without providing a "professor of books." As Emerson realized, academic libraries serve little purpose if students are not taught how to utilize their resources. Libraries serve less purpose if students are not required by their professors to use them as part of their coursework. The struggle to make the library an integral part of the educational process is a long-standing one which has yet to be resolved.

Of course, it is an oft-repeated truism that the library is the heart of the college. In many institutions, however, the library has been relegated to a peripheral role in education. If evidence were needed of the neglect of the library by most undergraduates, that evidence was provided by Ernest Boyer in his book, College: The Undergraduate Experience in America. Boyer reported that in a normal week one of every four undergraduates spends no time in the library and $65 \%$ spend four or fewer hours there. ${ }^{2}$

\footnotetext{
'Ralph Waldo Emerson, "Books," Atlantic Monthly 1 (1858): 343-53.

${ }^{2}$ Ernest L. Boyer, College: The Undergraduate Experience in America (New York: Harper and Row, 1987), 160-63.
}

As Boyer's book clearly shows, in most academic institutions today there is a wide gap between the classroom and the library. In many classes the only reading that is done is out of a textbook, and in many others, the only use of the library is to do reserve reading. Boyer, however, strongly advocates that the library be moved to the center of undergraduate education. He writes:

"The college library must be viewed as a vital part of the undergraduate experience. . . The library staff should be considered as important to teaching as are classroom teachers. ... Students should be given bibliographic instruction and be encouraged to spend at least as much time in the library-using its wide range of resources - as they spend in class."

Throughout his book, Boyer stresses the importance of students becoming independent learners. In emphasizing the independent learner, Boyer echoes a theme found in a whole series of reports published during the decade of the 1980s that focused on the topic of improving education in the United States. The first report, A Nation at Risk, issued in 1983, assessed the state of elementary and secondary education. ${ }^{4}$ Four other reports focusing

${ }^{3}$ Boyer, 164-65.

${ }^{4}$ U.S. Department of Education, A Nation at 
specifically upon undergraduate education followed soon after. ${ }^{5}$ All of these reports asserted the importance of active learning. Faculty were urged to make greater use of active modes of teaching and require that students take greater responsibility for their learning. The reports emphasize the importance of more independence in the classroom, with "less telling and more asking and critiquing." 6 Again and again, the concept emphasized is "active learning." Students should not be treated as objects of learning but as colleagues in the learning process.

Among other worthy objectives, these reports provide an impetus for a new look at the role of the library in undergraduate education. In a world of rapidly expanding information and proliferating technology, undergraduate students need to be prepared for a future where they will continue to learn and be educated. As Harlan Cleveland wrote in "Educating for the Information Society," those "people who do not educate themselves--and keep re-educating themselves - to participate in the new knowledge environment will be the peasants of the information society." The library provides a laboratory where students can be trained to take a more active role in their own education and be taught how to learn not only for today but for the future. Librarians in consort with faculty members can empower undergraduate students to become independent, self-directed learners-not passive recipients of information. The academic library can play a vital role in ensuring that students acquire the skills and attitudes towards learning and information that will allow them to keep abreast of the rapid changes in this "information society."

Librarians and faculty have tried numerous times in the past one hundred years to give the library a larger role in the educational process of students, but none of these efforts have been completely successful. One of the most comprehensive endeavors to increase the role of the library

Risk: The Imperative for Educational Reform (Washington, D.C.: National Commission on Excellence in Education, 1983).

${ }^{5}$ These reports are: To Reclaim a Legacy (Washington, D.C.: National Endowment for the Humanities, 1984); Involvement in Learning: Realizing the Potential of American Higher Education (Washington, D.C.: National Institute of Education, 1984); Frank Newman, Higher Education and the American Resurgence (Princeton, N.J.: The Carnegie Foundation for the Advancement of Teaching, 1985); Frederick Rudolph, Integrity in the Undergraduate Curriculum (Denver: Educational Commission of the States, 1986).

${ }^{6}$ Newman, xi.

${ }^{7}$ Harlan Cleveland, "Educating for the Information Age," Change 17 (July/August 1985): 21. can be found in the library-college movement that began in the 1930s. The proponents of the librarycollege concept thought that the library instead of the classroom should be the major source of a student's learning. A student would learn by means of independent study carefully planned by both the student and by bibliographically expert faculty members to achieve a specific aim. Advocates of the library-college envisioned students freed from the rigidly prescribed lockstep of classroom, lectures and grades pursuing educations that would be truly centered on their specific needs.

The library-college concept was an intriguing idea, and elements of the library-college philosophy were adopted by a number of institutions. Louis Shores, an early proponent of this philosophy, estimated in 1975 that some 300 colleges were using some elements of the library-college model. ${ }^{8}$ Ultimately, however, no institutions ever evolved into pure library-colleges, but this model is certainly worth a reexamination today as one method of making students more "active" learners.

This is an ideal time to rethink the relationship between the library and the classroom. As a result of the reports discussed earlier, many institutions of higher education are reexamining their undergraduate curricula and are putting a new emphasis on the proactive student and the process of disciplined inquiry at the undergraduate level. The objective of creating a more dynamic learning environment for undergraduates cannot be carried out fully without the active involvement of the library and the librarians. The relationship between the classroom and the library needs to be restructured and a new partnership forged, with the library playing an expanded role in undergraduate education. Although not a library-college in the strictest sense, there would be elements of the library-college model contained in this new cooperative venture.

The gap between the classroom and the library that Boyer discussed has to be bridged, but librarians alone can not provide the bridge. A partnership between the library and the classroom cannot be created without the cooperation of the teaching faculty. Librarians have often rightly been accused of insularity and for caring more about acquisition and preservation of library collections than their use. Those attitudes have been discarded by most academic librarians in the past few decades as librarians have become more user oriented and have attempted to educate students about library resources. In most colleges and universities, librarians have instituted bibliographic instruction programs and have created subject bibliographies,

${ }^{8}$ Louis Shores, "Library College: Prototype for Universal Higher Education," The Encyclopedia of Library and Information Science, 1975, p. 465. 
self-paced library resource manuals and other user aids. Some of these librarians have been assisted by interested faculty, but the number of faculty who are actively involved in this effort is small. Library instruction succeeds best when it is an integral part of a student's coursework, and most faculty have not integrated library resources into their teaching. But, there are some convincing arguments that can be mustered in favor of more library-centered education.

First, this method can be more individually tailored to the needs of the individual learner. Students differ greatly in their ability, motivation and cognitive styles, and these differences have important consequences for the way in which students learn. The library could provide multi-media approaches to gathering information about the same topic, and students would be able to utilize their preferred learning styles.

In addition, a more library-centered curriculum would be better able to match the developmental needs of students. Even within the traditional 18-22 year college age span, students may be in many different developmental stages. Add to this the non-traditional students, some coming to college for the first time and others returning for continuing education, and it becomes very difficult to shape a classroom experience that meets all of these developmental needs. The more individualized library-centered curriculum would be more flexible in meeting these needs.

This method of learning would also be more like the real world for which students are preparing. After graduation, students will not learn from lectures and lists of reserve books. They need to be prepared for this future now by being taught how to gather, evaluate, and utilize sources on their own. They need to be taught while in college how to develop patterns of critical thinking which they can use as effectively after graduation as during their college days.

In addition, library-centered learning would give the faculty a unique chance to do some modelling for the students. Faculty members expect to transmit knowledge by lecture, but how much of their learning do they get by that means? How often does a college professor sit in on a class offered by another? Not often. They gain new knowledge by reading journals, exchanging references, talking to colleagues and keeping up with the literature that appears in their fields. In short, their learning takes place outside the classroom. Faculty should teach students to learn in the same way that they do their own learning.

Even when faculty are convinced that a more library-centered learning process is superior to the traditional classroom methods, the new partnership between library faculty and teaching faculty will not be easy to achieve because it will require basic changes in the way each group functions. But a powerful outside force is already impelling both faculty and librarians to rethink their purpose and function-that is the force of the new technologies which are slowly infiltrating higher education. On many campuses the new information technologies are requiring a reexamination of how students should be taught and how scholarly information should be provided and made accessible. Some schools such as Brown, Carnegie-Mellon, and MIT have invested heavily in the computerization of their campuses and already have networks in place for campus-wide information sharing. At these institutions, computers are being used in classroom teaching and for linking faculty, students and libraries. But most colleges and universities are still not fully utilizing the technology that is available, and so there has not yet been sufficient time to study how this innovation may change the lives of faculty, students, and, indeed, the very nature of higher education.

It seems likely that the educational revolution being driven by technological forces will force the academic library into a more centralized role in undergraduate education while at the same time providing the means to make this change viable. For, with the advent of the new technologies, the library is at last able to escape the boundaries of its physical location.

One of the major reasons that the library-college concept discussed earlier did not succeed was because it called for a sweeping realignment of learning with all learning taking place within the physical confines of the library building. The new technologies make the library-college concept possible because the resources contained in the library can now be made available not just in the library but across campus as well. In addition, by the use of library networks, the resources of libraries across the country will also be available to faculty and students through their individual computer workstations.

Most campuses do not yet have the technology available to begin the restructuring of higher education, but every campus has the capability to begin now to make its education more library centered; then, when the technological infrastructure is in place, it will be able to utilize it fully. What should be done now to encourage an expanded role of the library in undergraduate education?

First, the faculty need to be encouraged to move away from the lecture/textbook method of education to a more library-centered one. Before they are going to do this, however, many faculty members will need to be re-educated about the resources and the technology already available in the library. Librarians need to work harder at keeping faculty informed and up-to-date about the library. Libraries have changed more in the past few dec- 
ades than they had in hundreds of years. Technology has provided the means to offer services and to access materials in ways never possible before. Even librarians who work closely with these new technologies and resources have to struggle to stay abreast of the changes. It is little wonder that individuals who use a library infrequently are often overwhelmed by the changes in the materials available and the services offered even in their own subject areas. Faculty must be apprised of what is available because only when faculty themselves feel comfortable using the resources of the library, will they be likely to have their students use them.

Faculty should be encouraged to work to develop library centered assignments. There are some liberal arts colleges, for example, Earlham, which have already instituted more library-centered curricula. Class units based on library research, learning contracts, and independent study are all being utilized. Ideas from colleges such as these should be disseminated to the faculty, and perhaps some faculty and librarians could visit them to see how library-based education works.

As colleges struggle to change their curricula to make the student a more active participant in the learning process, librarians must stay familiar with what is being planned. Librarians should be placed on committees which deal with the restructuring of the curriculum and assigned to work as liaisons with specific departments on campus. Many librarians have advanced subject area degrees and could be encouraged to work with faculty in developing library-based courses. In some cases, courses could be team taught by regular faculty and by librarians. As more colleges invest in computer technology to be used in teaching, librarians can work with faculty to develop the courseware necessary to utilize the technology.

Conversely, when the library plans for new technology, the librarians should work closely with teaching faculty in deciding what technological resources would be most effective in providing the linkages needed to bridge the gap between the classroom and the library. In addition, there should be a campus-wide committee in place to plan for the integration of all the learning resources on campus.

Finally, and perhaps most important, to make this partnership succeed there must be a strong institutional commitment to support the necessary changes. Campus leaders must support and encourage the integration of library and classroom learning. Without the support and encouragement of administration, lasting change is unlikely.

These are the types of changes that need to be instituted now, so that universities and colleges will be able to make wiser decisions about the larger changes that will undoubtedly be confronting them in a few years when their campus networks are in place and powerful scholars' workstations make easy sharing of information between faculty, students, and the library possible. These changes will also enable institutions to be better able to cope with the likely transformation of traditional higher education.

Some futurists have predicted that colleges of the future will be completely deinstitutionalized. Students will cease to attend classes because they will be able to learn at home with the aid of computers. These prophets foresee the disappearance of both the college and its libraries as their functions are replaced by electronic technology.

It seems unlikely that a change this drastic will occur anytime in the near future. Most students need the human contact found in interactions with other students and faculty. But, it does seem likely that the day of the lecture, textbook and reserve reading list are numbered. Technology will provide a means for students to move at an individualized pace through learning materials. Hypertext-based learning systems will allow students to draw together the work of outside authorities, other students, and their teachers and then add their own contributions. Both the full-text and bibliographic resources of the library will be available to students in their classrooms and dormitories. Multimedia resources will be easily accessible and utilized in combination with traditional print media. Faculty will use both commercial and self-created courseware to create interactive learning experiences.

These new information technologies have the capacity to transform the world of higher education and to turn every student into an active learner. When the physical barriers separating the classroom and the library no longer exist, the librarycollege concept will be able to succeed. The library will become an integral part of the classroom experience because the library can become part of every classroom (and dorm room and faculty office).

We are still a few years away from this future, but colleges and universities should be working now to prepare for it. Ernest Boyer states that quality in higher education can be measured by the resources available for learning and the extent to which students are encouraged to become independent, self-directed learners. ${ }^{9}$ Perhaps this statement can be carried one step further. It seems likely that the institutions which now are trying to improve their learning resources and to make their students independent learners will be the institutions best able to make the transition to the new world of higher education.

Author's Note: This article is adapted from a speech made at the rededication of Myrin Library, Ursinus College, in November 1989.

${ }^{9}$ Boyer, 160. 